Agata A. Kluczek (Katowice)

\title{
BARbarians ON THE COINS OF Trajan Decius (249-251)
}

$\mathrm{T}$ he theme of the barbarian, especially its variants which presented the barbarian as an enemy or a captive, was an ideologically expressive symbol utilised in Roman art and mintage across centuries ${ }^{1}$. It symbolised victory and the capability of conquering a specific person or an entire empire; it expressed the idea of Roman victory and dominance in the ancient world. In the middle of the $3^{\text {rd }}$ century one is struck by its absence in imperial coinage. It falls to the socalled first great crisis (249-253) ${ }^{2}$, which covered the reign of a number of rulers: Trajan Decius and his sons Herennius Etruscus and Hostilian (249-251), Trebonianus Gallus and Volusianus (251-253), as well as Aemilianus (253). The lack of this theme in imperial coinage is intriguing. In the third century, during a time of wars which justified and enforced the presence of the theme, and in the period of a glorification of the emperor as the victor and the unconquerable leader of an empire, the figure of a stranger-enemy was transposed to the reverses of coins, whose content touched upon various spheres of state-social life, not only of military questions ${ }^{3}$. The absence of the images of the barbarians is surprising

${ }^{1}$ Cf. (e.g.) J.A. Ostrowski, „Cum restrictis ad terga manibus”. Wizerunki jeńców wojennych jako element rzymskiej propagandy politycznej, [in:] Niewolnictwo i niewolnicy w Europie od starożytności po czasy nowożytne, ed. D. Quirini-Pop£awska, Kraków 1998, p. 41-47; S.P. Mattern, Rome and the Enemy. Imperial Strategy in the Principate, Berkeley-Los Angeles-London 1999, p. 171-202; I.M. Ferris, Enemies of Rome. Barbarians through Roman Eyes, Stround 2000; L. Hannestad, War and Greek Art, [in:] Essays on Warfare in Antiquity, ed. T. BeKker-Nielsen, L. Hannestad, København 2001, p. 146-154. Cf. also: T. Kotula, Barbarzyńcy i dworzanie. Rzym a barbarzyńcy w dworskiej literaturze późnorzymskiej, Kraków 2004, p. 34-112.

All illustrations from cngcoins.com. I thank the Classical Numismatic Group, Inc. for their consent to my using the photographs of the coins free of charge.

${ }^{2}$ Cf. M. Christol, L'empire romain du III siècle. Histoire politique (de 192, mort de Commode à 323, concile de Nicée), Paris 1997, p. 121-130.

${ }^{3}$ Cf. A.A. KLUCZEK, Wizerunek „obcego-wroga” w ikonografii monetarnej. Przykład mennictwa cesarza rzymskiego Aureliana (270-275), [in:] Grecy, Rzymianie i ich sasiedzi, ed. K. NawotKA, M. PAwLak, A. PaŁuchowski, A. Wojciechowska, Wrocław 2007, p. 305-326; Eadem, Empereur invaincu 
in the typologically rich mintage of the aforementioned rulers (consecutively, $226,264$ and 64 types of coins) $)^{4}$. It is assumed that it might have been caused by the echoes of failures in the Gothic war, such as the siege of Novae on the Danube and Nicopolis ad Istrum, the fall of Philippopolis in Thrace (250), the destruction of Marcianopolis, the lost battle at Abritus in Moesia Inferior (251), and finally the death of the emperors Herennius Etruscus and Trajan Decius incurred in the fighting against the Goths $(251)^{5}$.

However, the theme of the barbarian was featured in the provincial coinage of Trajan Decius. The ordering of the provincial coins of the period of his reign in the Roman Provincial Coinage enables one to engage in a discussion on this subject ${ }^{6}$.

The representation of an enemy or a captive found its way on coins whose obverses feature the portrait of either Trajan Decius himself or the caesar Herennius Etruscus, the elder son of the emperor. They were issued in four mints: Nicomedia, Caesarea Maritima, Magnesia ad Sipylum, Alexandria. Taken as a whole, it is not a large group of issues (cf. Appendix).

\section{Iconographic models - coins featuring the barbarian theme}

In the iconography of coin reverses, barbarians were juxtaposed in various configurations with a mounted horseman (cf. figs 1-3), the goddess of victory or a tropaion - a symbol of victory (cf. fig. 4). The barbarian(s) was or were depicted below the steed whereas the Roman rides at a trot ("pacing horse") or at a gallop ("galloping-horse series"). The relations of the barbarians with the Roman empire were also represented by means of a scene in which a Roman is armed with a spear, and fighting the enemies, trampling them down on horseback. The former reach

et barbares. Les représentations des barbares dans le monnayage romain de l'époque impériale (235284 apr. J.-C.), [in:] Rzym antyczny. Polityka i pieniadz. The Ancient Rome. Politics and Money IV, ed. W. KaCZanowicz, Katowice 2008, p. 104-134; EADEM, VNDIQVE VICTORES. Wizja rzymskiego władztwa nad światem w mennictwie złotego wieku Antoninów i doby kryzysu III wieku - studium porównawcze, Katowice 2009, p. 233-236, 249-295.

${ }^{4}$ C. Heitz, Alles bare Münze? Fremdendarstellungen auf römischem Geld, BJ 206, 2006, p. 205.

${ }^{5}$ A.A. KluczeK, VNDIQVE VICTORES..., p. 253-254, 293-294. The Gothic war (250-251): T. KoTULA, Kryzys III wieku w zachodnich prowincjach cesarstwa rzymskiego, Wrocław 1992 [= AUW.A], p. 23-24; IDEM, Cesarz Klaudiusz II i Bellum Gothicum lat 269-270, Wrocław 1994 [= AUW.A], esp. p. 74-76; U. Huttner, Von Maximinus Thrax bis Aemilianus, [in:] Die Zeit der Soldaten-Kaiser. Krise und Transformation der Römischen Reiches im 3. Jahrhundert n. Chr. (235-284), ed. K.-P. JohnE, U. Hartmann, T. Gerhardt, Berlin 2008, p. 208-211; L. Grozdanova, The Roman Emprerors against the Goths of Cniva. Political Mythology, Historical Documents and Retrievable Reality, Sofia 2019, p. 81-117. The numismatic 'remains' after the war: A. Bursche, The Battle of Abritus, the Imperial Treasury and Aurei in Barbaricum, NC 173, 2013, p. 151-170.

${ }^{6}$ A. Hostein, J. Mairat, Roman Provincial Coinage, vol. IX, From Trajan Decius to Uranius Antoninus (AD 249-254), London-Paris 2016 (cetera: RPC 9). 
their hands to their conqueror; they lay or sit on the ground or they run away. Other reverses depict captives who sit or kneel below the tropaion.

The reverse representations of coins of Trajan Decius with the barbarian theme, if one disregards slight differences in the arrangement of details, may be classified within six basic iconographic models ${ }^{7}$ : a horseman and an enemy who sits; a horseman and a fleeing enemy; a horseman riding at a gallop and an enemy; a horseman riding at a gallop and two enemies; Nike, tropaion and a captive; a tropaion and two captives. The first of these models was featured in three varieties.

The distribution of these models and their varieties in the particular mints, which also takes into account a reference, on the obverse, to the figure of the emperor or caesar is presented in Table 1 .

Table 1

The barbarian theme in provincial coinage 249-251 - iconographic models

\begin{tabular}{||c|l|c|c|c|c||}
\hline $\begin{array}{c}\text { Item } \\
\text { no. }\end{array}$ & \multicolumn{1}{|c|}{ Reverse theme } & $\begin{array}{c}\text { Nico- } \\
\text { media }\end{array}$ & $\begin{array}{c}\text { Caesarea } \\
\text { Maritima }\end{array}$ & $\begin{array}{c}\text { Magnesia } \\
\text { / Sipylos }\end{array}$ & $\begin{array}{c}\text { Alexan- } \\
\text { dria }\end{array}$ \\
\hline 1 & a horseman, a sitting enemy & TD & & & \\
\hline 2 & a horseman, a fleeing enemy & TD & & & \\
\hline 3 & a horseman riding at a gallop, an enemy & & TD, HE & & HE \\
\hline 4 & a horseman riding at a gallop, two enemies & & & TD & \\
\hline 5 & Nike crowning a tropaion, a kneeling captive & & & TD & \\
\hline 6 & a tropaion, two sitting captives & & & & TD \\
\hline
\end{tabular}

TD - Trajan Decius

HE - Herennius Etruscus

\section{The activities of provincial mints and the barbarian theme}

From the years 249-251, eighty-four provincial mints operated there. They functioned with varying intensity, releasing a varying number of emissions (the total number of issues is 1219). The mint in Antioch (Syria Coele, Syria) was the most active one, with a record-breaking number of issues: 185 (it is almost 16\% of all

\footnotetext{
${ }^{7}$ Here I distinguish the iconographic model from the type defined with a reverse inscription. I take into account only the elements of the iconography.
} 
provincial issues between the years $249-251)^{8}$. The second place is occupied by Alexandria ad Aegyptum (Egypt) - 77 issues ${ }^{9}$, further on there are the following: Caesarea Maritima (Syria Palaestina, Samaria) $-64^{10}$, Tarsus (Cilicia) $-48^{11}$, Nicaea (Bithynia-Pontus, Bithynia) $-47^{12}$, Rhesaena (Mesopotamia) $-46^{13}$, Viminacium (Moesia Superior, Moesia) $-44^{14}$, Ephesus (Asia, Ionia) ${ }^{15}$ and Samos (Asia, Ionia) ${ }^{16}$ - 40 issues each, Aelia Capitolina (Syria Palaestina, Judaea) - $34^{17}$, and Anazarbus (Cilicia) - 32 issues ${ }^{18}$. The twelfth place was occupied by Nicomedia (BithyniaPontus, Bithynia), where the number of issues was $30^{19} .56 \%$ of all provincial issues of the period of Trajan Decius's reign originate from the twelve centres which were mentioned. The remaining mints operated less actively; in some of them, the number of the issues was well below the average level. Between 25 and 15 issues - 9 mints; less than 15 issues - a total of 63 mints. In the latter group, there is Magnesia ad Sipylum (Asia, Lydia) with six issues ${ }^{20}$, and other mints in which, in extreme cases, three ${ }^{21}$, two $^{22}$, and sometimes single issues were developed ${ }^{23}$.

On the one hand, the barbarian theme was introduced in coins in major mints, which boasted copious production (these are the following: Alexandria, Caesarea Maritima, and to a certain extent also Nicomedia), and, on the other hand, in a mint in which few emissions were developed (Magnesia ad Sipylum). The distribution

\footnotetext{
${ }^{8} R P C$ 9, nos 1602-1786.

${ }^{9} R P C$ 9, nos 2220-2296.

${ }^{10} R P C$ 9, nos 2048-2111.

${ }^{11}$ RPC 9, nos 1342-1389.

${ }^{12} R P C$ 9, nos 240-255, 255A, 256-273, 273A, 274-284.

${ }^{13}$ RPC 9, nos 1556-1601.

${ }^{14} R P C$ 9, nos $1-43,21 \mathrm{~A}$.

${ }^{15} R P C$ 9, nos 604-605, 605A, 606-642.

${ }^{16}$ RPC 9, nos 665-704.

${ }^{17} R P C$ 9, nos 2175-2208.

${ }^{18}$ RPC 9, nos 1467-1472, 1472A, 1473-1497.

${ }^{19}$ RPC 9, nos 318-346, 346A.

${ }^{20} R P C$ 9, nos $571-576$.

${ }^{21} 6$ mints, see: RPC 9, nos 991-993: Andeda (Lycia-Pamphylia, Pisidia), 777-779: Aphrodisias (Phrygia-Caria, Caria), 1179, 1179A, 1180: Casae (Lycia-Pamphylia, Cilicia), 986, 986A, 987: Comama (Lycia-Pamphylia, Pisidia), 1200-1202: Laerte (Lycia-Pamphylia, Cilicia), 705-707: Priene (Asia, Ionia).

229 mints, see: RPC 9, nos 1419-1420: Adana (Cilicia), 663-664: Anineta (Asia, Lydia), 1310-1311: Antiochia ad Cragum (Cilicia), 224-225: Apamea (Bithynia-Pontus, Bithynia), 1194-1195: Carallia (Lycia-Pamphylia, Cilicia), 994-995: Panemoteichus (Lycia-Pamphylia, Pisidia), 1136-1137: Sillyum (Lycia-Pamphylia, Pamphylia), 1221-1222: Sinope (Galatia-Pontus, Paphlagonia), 963-964: Tityassus (Lycia-Pamphylia, Pisidia).

${ }^{23} 4$ mints, see: RPC 9, no 208: Caesarea Germanica (Bithynia-Pontus, Bithynia), 970: Colbasa (Lycia-Pamphylia, Pisidia), 907: Hadrianopolis (Phrygia-Caria, Phrygia), 788: Laodicea ad Lycum (Phrygia-Caria, Phrygia).
} 
of the number of iconographic models, among which there were those in which the image of the barbarian was introduced, is represented in Table 2 against the background of the number of issues - all issues and the ones which feature the barbarian theme - in these four mints.

Table 2

Provincial mintage 249-251 - the barbarian theme

\begin{tabular}{|c|c|c|c|c|c|}
\hline \multirow{2}{*}{$\begin{array}{c}\text { Item } \\
\text { no. }\end{array}$} & \multirow{2}{*}{ Mint } & \multirow{2}{*}{$\begin{array}{c}\text { Aggregated } \\
\text { number of } \\
\text { issues }\end{array}$} & \multirow{2}{*}{$\begin{array}{c}\text { Aggregated } \\
\text { number } \\
\text { of iconographic } \\
\text { models }\end{array}$} & \multicolumn{2}{|c|}{ The barbarian theme } \\
\hline & & & & $\begin{array}{l}\text { Number } \\
\text { of issues }\end{array}$ & $\begin{array}{c}\text { The number } \\
\text { of iconographic } \\
\text { models }\end{array}$ \\
\hline 1 & Alexandria & 77 & 28 & $6(8 \%)$ & $2(7 \%)$ \\
\hline 2 & $\begin{array}{l}\text { Caesarea } \\
\text { Maritima }\end{array}$ & 64 & 32 & $2(3 \%)$ & $1(3 \%)$ \\
\hline 3 & Nicomedia & 30 & 22 & $3(10 \%)$ & $2(9 \%)$ \\
\hline 4 & $\begin{array}{l}\text { Magnesia } \\
\text { ad Sipylum }\end{array}$ & 6 & 5 & $3(50 \%)$ & $2(40 \%)$ \\
\hline
\end{tabular}

The activities of major mints in Alexandria ${ }^{24}$ and Caesarea Maritima ${ }^{25}$ and the considerable typological variety of their products do not correlate with the considerable amount of coins which feature the barbarian theme. The other side of the spectrum is occupied by the case of Magnesia ad Sipylum. Its peculiar nature cannot be emphasised by absolute numbers which specify the number of the issue in general and the number of issues with the barbarian theme - this was after all a centre of minor activity, therefore these numbers are appropriately low. This peculiar nature is determined by the high percentages which define the contribution of the barbarian theme in the bulk of the issue (even as much as $50 \%$ ) and the iconographic models in general (40\%). Finally, Nicomedia, in the terms which are indicated here, somehow yields the average of the presence of the number of issues with the barbarian theme and of iconographic models with the barbarian theme.

\footnotetext{
${ }^{24}$ Cf. W. Kellner, Die Münzstätte Alexandria in Ägypten von Kleopatra bis Arcadius, Wien 2009, p. $42-43$.

${ }^{25}$ Cf. L. Levine, Some Observations on the Coins of Caesarea Maritima, IEJ 22.2/3, 1972, p. 135sqq.
} 


\section{The barbarian theme in the iconographic tradition of the Nicomedia, Caesarea Maritima, Alexandria and Magnesia ad Sipylum mints}

Nevertheless, the Nicomedia and Caesarea Maritima mints are interesting because - in light of the familiar coins which were emitted there - a novelty, in reference to the coins of Trajan Decius's reign, was associated with the introduction of a Roman horseman who aims his spear at the enemy who is sitting or lying on the ground or who is running away from his conqueror. Such an arrangement of the scene had not been featured in the products of both of these mints. Indeed, in Nicomedia the theme of an emperor riding a horse at a gallop was previously used, but there was no figure of the enemy. However, already in the subsequent period such an addition appeared in Gallienus's coinage (253-268): the reverses of his coins from Nicomedia bear the representation of the emperor on horseback who is fighting two horseless enemies ${ }^{26}$.

The local numismatic tradition associated with the barbarian theme was different in the case of the two remaining mints, Alexandria and Magnesia ad Sipylum: here one may find the iconographical patterns of the representations featured on Trajan Decius's coins.

In Alexandria, the instances of inspiration which were found date back above all to the period of Trajan's reign (98-117), for it was at that time that many iconographical solutions were introduced by means of which - incorporating the barbarian theme in them - the victorious power and the success of this emperor were expressed. Among them one may find an image consisting of a tropaion and two captives who are sitting beneath it. Sometimes it was embedded in a more comprehensive scene ${ }^{27}$, and sometimes his figure alone filled the reverse ${ }^{28}$. Another representation which was promoted on Trajan's coins has to do with a horseman who dominates above a barbarian. A horseman, who is holding a sceptre and a parazonium, his horse pacing; a barbarian kneels before him and stretches his hand toward him ${ }^{29}$. In other coins, a horseman, armed with a spear, rides a horse

\footnotetext{
${ }^{26}$ See: http://www.coinproject.com/coin_detail.php?coin=216954 [27 XII 2019].

${ }^{27}$ Cf. (e.g.) M. Amandry, A. Burnett, J. Mairat, W. Metcalf, L. Bricault, M. Blet-Lemarquand, Roman Provincial Coinage, vol. III, Nerva, Trajan and Hadrian (AD 96-138), London-Paris 2015 (cetera: RPC 3), no 4381 (AD 109/110): emperor, laureate-headed, seated facing from the throne, between trophy with captive and a captive; nos 4806.1-3 (AD 113/114), rv.: L IZ; Nike advancing, l., holding wreath and palm-branch; to 1., trophy with standing Armenian captive and kneeling Armenian captive; G. Dattari, Numi Augg. Alexandrini, Cairo 1901, no 717; https://www.cngcoins.com/ Coin.aspx?CoinID=64019 [27 XII 2019], rv.: emperor seated on curule chair, 1., holding Nike and sceptre; trophy and supplicant before him, L IZ above.

${ }^{28}$ RPC 3, nos 4153 (101/102), 4161 (102/103), 4188 (105/106), 4338.1-6 (108/109), 4457.1-4 (109/110), 4548 (110/111), 4559 (110/111), 4697 (112/113), 4697A, 4750 (112/113). See also: RPC 3, nos 4339.1-2 (108/109), rv.: trophy with captives, one standing, L IB.
}

${ }^{29}$ RPC 3, no 4971 . 
at a gallop, and below - under the hooves of the horse - there lies an enemy who stretches his hand toward him ${ }^{30}$.

In Alexandrian coinage both iconographic models - a horseman confronting an enemy ${ }^{31}$ and a tropaion and captives ${ }^{32}$ - were recurrent themes featured on coins of successive rulers. This second representation became especially popular. One also observed a particular situation, which had to do with the use of the theme of a tropaion and captives in Alexandria. It was represented in reverses even when it continued to be rarely represented in provincial coinage and it was not featured in imperial coinage, which happened in the first half of the $3^{\text {rd }}$ century ${ }^{33}$.

Both iconographic models used in the tetradrachms of Trajan Decius therefore belong to items which were used in Alexandria and ones that were more or less popular since Trajan's reign. Even though these rulers share a cognomen adopted by Decius (Imperator Caesar C. Messius Quintus Decius Traianus Augustus ${ }^{34}$ ), the thread which was thus created between them results in this case from a numismatic iconographical tradition, and to one that was associated not only with the Alexandrian mint. Both the image of the horseman mounted on a galloping

\footnotetext{
${ }^{30}$ RPC 3, no 4665 (112/113: L IC).

${ }^{31}$ C. Howgego, Roman Provincial Coinage, vol. IV.4, The Antonines (AD 138-192): Egypt (online) (cetera: RPC 4.4), no 14188 temp. (Commodus, 180/181), rv.: L KA; emperor in military dress, brandishing thunderbolt (or spear), galloping, r., over fallen foe, wearing high cap, (holding shield,) and horse (?); G. Dattari, Numi Augg. Alexandrini..., no 3986 (Septimius Severus, 193-211), 4017 (Septimius Severus (Julia Domna)), 4079 Septimius Severus (Geta), 4699 (Gordian III, 238-244). The scene is supplemented by the figures of soldiers - RPC 4.4, no 14093 temp. (M. Aurelius, 166/167), rv.: [L Z](?); emperor in military dress galloping, l., brandishing spear; before and behind, soldiers holding shields; beneath hooves, fallen foe; beneath belly of horse, two foes, one fallen, the other seated.

${ }^{32}$ Antoninus Pius (138-161): RPC 4.4, nos 13526 temp., 15867 temp., 15171 temp., M. Aurelius: RPC 4.4, nos 14122 temp., 14683 temp., 14682 temp., 15190 temp., 15499 temp., 16910 temp., 16659 temp., M. Aurelius (Faustina II): RPC 4.4, nos 16491 temp., 16403 temp., M. Aurelius (Crispina): RPC 4.4., no 15090 temp., L. Verus (161-169): RPC 4.4, nos 14615 temp., 16203 temp., 16577 temp., 15084 temp., Commodus: RPC 4.4, nos 14168 temp., 14189 temp., 14518 temp., Severus Alexander (222-235): D. Calomino, A. Burnett, S. Matthies, Roman Provincial Coinage, vol. VI, From Elagabalus to Maximinus (AD 218-238) (online) (cetera: RPC 6), nos 10618 temp., 10647 temp., Severus Alexander (Julia Mamaea): RPC 6, nos 10638 temp., 10656 temp., Maximinus (235-238): RPC 6, nos 10711 temp., 10746 temp., Maximinus (Maximus): RPC 6, nos 10727 temp., 10761 temp.; Gordian III: G. DatTari, Numi Augg. Alexandrini..., nos 4802-4804. Trophy with captive - M. Aurelius: $R P C$ 4.4, nos 14082 temp., 15193 temp., L. Verus: RPC 4.4, nos 14116 temp., 14177 temp., 14501 temp., 14502 temp., 14503 temp., 16199 temp. Such a model [was featured] in the mintage of the $1^{\text {st }}$ century, Nero (54-68): A. Burnett, M. Amandry, P.P. Ripollès, Roman Provincial Coinage, vol. I, From the Death of Caesar to the Death of Vitellius (44 BC-AD 69), London-Paris 1992, no 5265, rv.: LH; trophy and captive kneeling in front.

${ }^{33}$ Cf. G.C. PiCARD, Les trophées romains. Contribution à l'histoire de la Religion et de l'Art triomphal de Rome, Paris 1957, p. 472-473.

${ }^{34}$ See: M. Peachin, Roman Imperial Titulature and Chronology, A.D. 235-284, Amsterdam 1990, p. 240-264, nos 3-4, 6-14, 16-19, 21-37, 39, 64-65, 67-70, 72-91, 134-138, 140, 144-161, 164-165.
} 
horse and fighting with an enemy lying on the ground, and the image composed of a tropaion and captives simply became recognised and gained wide currency in Roman coinage.

In Magnesia ad Sipylum, the bronze coins in which Aur. Artemas Menemachou Laianou strategos preserved his name, the iconography which was a longstanding staple in this centre was also utilised, even though it was featured only sporadically. In 180-182, it was introduced to the bronzes of Commodus, which bore the name of strategos Ail. Attikos Quadratos. A few types of coins are associated with his name ${ }^{35}$, including two which are of interest in the context that is considered. Both of them exhibit Nike crowning a trophy. One of the coins features a shield next to a trophy at the right-hand side ${ }^{36}$. One introduced another element in the second coin - a kneeling captive who occupied a place between Nike and the trophy, whereas the shield was moved to the left-hand edge of the representation ${ }^{37}$. After some years, strategos M. Aur. Gaius replicated the latter solution in the Caracalla's bronzes $(198-217)^{38}$. Subsequently, such iconography found it way on coins with the representation of caesar Philip Junior (caes. 244247, aug. 247-249), issued during the reign of Trajan Decius's predecessor, Philip the Arab (244-249) $)^{39}$. A slight correction was introduced in the coins of Trajan Decius - the shield which flanked the trophy at the left-hand side disappeared. Also the reign of Caracalla ${ }^{40}$ and that of the Philips ${ }^{41}$ are the source periods of the representation in which a horseman fights against two foes - a representation which was reiterated in the coinage of Trajan Decius.

\footnotetext{
${ }^{35}$ V. Heuchert, Roman Provincial Coinage, vol. IV.2, The Antonines (AD 138-192): Asia (online, with temporary numbers) (cetera: RPC 4.2), no 1331 temp.: Cybele seated in biga drawn by lions, 1 ., 1332 temp., 2837 temp.: temple enclosing statue of Cybele standing l., between two lions, 3135 temp.: river god (Hermos) reclining, 11426 temp.: wagon (quadriga or biga) drawn by horses or mules. ${ }^{36}$ RPC 4.2, no 1337 temp.; K. Kraft, Das System der kaiserzeitlichen Münzprägung in Kleinasien. Materialien und Entwürfe, Berlin 1972 [= IF, 29], p. 187, no 7.

${ }^{37}$ RPC 4.2, no 2360 temp.

${ }^{38}$ B.V. Head, A Catalogue of the Greek Coins in the British Museum. Catalogue of the Greek Coins of Lydia, Bologna 1964 [repr.] (cetera: BMCG), Magnesia ad Sipylum, p. 148, no 66.

${ }^{39}$ BMCG, Magnesia ad Sipylum, p. 153, no 89.

${ }^{40}$ L. Forrer, The Weber Collection of Greek Coins, vol. III.1, London 1926, no 6845.

${ }^{41}$ http://www.wildwinds.com/coins/ric/philip_II/_magnesiaAdSipy_Paris_713.jpg [29 XII 2019]. In the subsequent period, such a reverse was featured in Gallienus's coinage, see: Sylloge Nummorum Graecorum. The Royal Collection of Coins and Medals Danish National Museum. Lydia, Copenhagen 1947, no 273, rv.: ЕП СТР АYР ФРОNТ $\Omega$ NOC МАГNH CIП, emperor on horseback, r., below, two fallen enemies. Cf. also obv.: AVK M IOV ФІ $І$ IПОС, laureate, draped, cuirassed bust of Philip

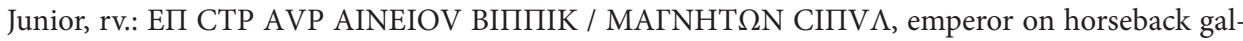
loping, r., bound captive kneels below: Sylloge Nummorum Graecorum Deutschland. Sammlung von Aulock. Lydien, vol. II, ed. G. KLEINER et al., Berlin 1963, Lydia, Magnesia, no 3006; https://collections.mfa.org/objects/259594 [23 XII 2019].
} 


\section{The theme of the barbarian in the dynastic ideology of Trajan Decius}

The Alexandria, Caesarea Maritima and Nicomedia mints were the centres where coins with obverses which bore the names and the portraits of all members of the dynasty were created: those of emperor Trajan Decius, empress Herennia Etruscilla, their sons Herennius Etruscus and Hostilian. The coins from Magnesia ad Sipylum do not feature the young dynasts. If we consider the iconographic models which were adopted here, then two were associated with the empress, and three other models were associated with the emperor - two of them saw the appearance of either a captive or an enemy. In three of the remaining mints, the number of the iconographic models is the following for Trajan Decius, Herennia Etruscilla, Herennius Etruscus and Hostilian, in Alexandria: 22, 4, 3, 3; in Caesarea: 25, 10, 11, 4; in Nicomedia: 18, 3, 4, 1, respectively. Some reverse representations remained unique for the individual members of the dynasty, while others were used in various family configurations.

From a dynastic perspective, it was mainly the emperor Trajan Decius who emitted the coins featuring the barbarian theme in all four mints ${ }^{42}$. It was only in Alexandria that the reverses of caesar Herennius Etruscus featured an iconographical theme which was absent on the coins of the emperor. Caesarea Maritima was the place where reverses bearing the same representation were issued for both of them. Caesar Hostilian, the younger son of Trajan Decius, was omitted.

Alexandria and Caesarea Maritima, two major mints, abound in material for the formulation of a number of remarks about the association of monetary themes with the members of Trajan Decius's family, the promotion of the dynastic unity and the ideology of victory.

In Alexandria, the figure of Nike appeared only on the tetradrachms of the emperor $^{43}$. Tetradrachms issued, for both his sons feature the image of a figure standing in armour and paludamentum, wearing a helmet and carrying a sceptre in her hand; she is sometimes identified as Roma ${ }^{44}$. Only the reverses which represent the head of Zeus were repeated on the coins of three male members of the dynasty ${ }^{45}$. There was a prevalence of iconographic models used in individual cases in coins struck for specific people; there is a paucity (about 10\%) of representations which are common for the dynasts. The themes which represent the ideology of victory, including the themes of the barbarian and Nike, provided a basis for the development of a small number of iconographic models (slightly more than 10\%).

\footnotetext{
${ }^{42}$ Nicomedia - RPC 9, nos 325, 326, 327; Magnesia ad Sipylum - RPC 9, nos 572, 573, 574; Alexandria - RPC 9, nos 2256, 2257, 2279.

${ }^{43} R P C$ 9, nos 2226, 2227, 2250, 2251, 2252, 2275, 2276: Nike advancing., r., holding wreath and palm; $R P C$ 9, no 2249: Nike seated 1., on cuirass, holding wreath and palm.

${ }^{44}$ Herennius Etruscus - RPC 9, nos 2262, 2291, 2292; Hostilian - RPC 9, no 2295.

${ }^{45}$ Decius - RPC 9, nos 2258, 2283, 2284; Herennius Etruscus - RPC 9, no 2293; Hostilian - RPC 9, no 2296.
} 
The promotion of the dynasty associated with the ideology of victory is more pronounced in the content of coins originating from Caesarea Maritima. Many iconographic models made reference to military subjects (more than $30 \%{ }^{46}$. There were representations of Nike / Victoria, whose attributes included a wreath and an olive twig, and the goddess was marching ${ }^{47}$, standing in a place ${ }^{48}$, or standing on a globe ${ }^{49}$. In other bronzes she was holding vexilla in her hand ${ }^{50}$. Further pieces presented Nike / Victoria in front of the emperor (fig. 5) ${ }^{51}$. Differently than in the case of the Alexandria mint, in Caesarea the theme of the goddess of victory was associated with both Trajan Decius, and with caesar Herennius Etruscus. In this case, coins were also issued with obverses for Herennia Etruscilla and for Herennius Etruscus, which depicted in one representation three members of the ruling family: the empress, flanked by two togati, extending hands to each other; one perceives in them the emperor and the elder son (fig. 6) ${ }^{52}$. This is a relatively rare solution in provincial coinage which symbolises the unity of the family and the cooperation of the rulers. Hostilian is not a part of this group, even though on the coins from other mints which operated in the period 249-251, in one representation, a group of three people consisting of the emperor and his sons ${ }^{53}$, or two brothers ${ }^{54}$. In Caesarea, many of reverse iconographic models (more than $30 \%$ ) were reiterated in coins with obverses of various members of the domus Augusta. The names and the representations of all of them, of the whole group of four people, found their way on coins with reverse themes: Tyche ${ }^{55}$ and the sitting Roma with a figurine of the goddess of victory in her hand (fig. 7$)^{56}$.

\section{The barbarian theme - the ideology of victory and "regionalisms" in the coinage of Trajan Decius}

In provincial coinage of Trajan Decius, the figures of the barbarians are either small in reference to the victorious representatives of the Roman side or they are "normal" in size. The latter option refers to some coins from Alexandria: a Roman and an enemy who attacks him are represented as equal in (physical) size. The

${ }^{46}$ Decius - RPC 9, nos 2059, 2060, 2061; Herennius Etruscus - RPC 9, no 2083.

${ }^{47}$ Decius - RPC 9, no 2070; Herennius Etruscus - RPC 9, no 2089.

${ }^{48}$ Decius - RPC 9, no 2072.

${ }^{49}$ Herennius Etruscus - RPC 9, no 2088.

${ }^{50}$ Decius - RPC 9, no 2071.

${ }^{51}$ Decius - RPC 9, no 2058.

${ }^{52}$ Herennia Etruscilla - RPC 9, no 2077; Herennius Etruscus - RPC 9, no 2082.

${ }^{53}$ RPC 9, nos 972: Cremna (Lycia-Pamphilia, Pisidia), 1469, 1483: Anazarbus (Cilicia, Cilicia Pedias).

${ }^{54} R P C$ 9, nos 2201-2205: Aelia Capitolina (Syria Palaestina, Judaea), 2212-2214, 2219: Bostra (Arabia).

${ }^{55}$ RPC 9, nos 2096-2099, 2101-2104, 2107-2111.

${ }^{56}$ RPC 9, nos 2065, 2078, 2085, 2090. 
former option is more common. Below the steed which is mounted by the Roman, there are the "small barbarians", who are as if artificially superimposed on the scene. According to Annalina Caló Levi:

It is evident that the small physical size of the barbarian is a device which emphasizes his abject position in contrast to the victorious emperor or divinity. [...] At first the barbarian is a symbol of a people recently vanquished by the emperor. Later the connection with an actual victory is less often found ${ }^{57}$.

In the $3^{\text {rd }}$ century, the "small barbarians" indeed performed the function of an attribute of the Roman rulers and deities.

In the years of Trajan Decius's reign, during which there were no instances of success in the fight against barbarians, the "small barbarians" are a metaphor for the greatness of the Roman and his power to be victorious. The issuing of coins both with "small barbarians" and with "normal-sized" barbarians, however, was spectacular in his coinage, even though it was limited to a few mints. It seems that the issues which were indicated also made reference - content-wise - to the aura induced by the concerns associated with the real barbarians Trajan Decius was confronted with during his reign. Such a complex assessment of the presence of the barbarians in the provincial coins of Trajan Decius neatly supplements and enhances his image which emerges from the content of the imperial coins.

In imperial coinage of Trajan Decius, there are very few references to foreign peoples. The inscriptions and representations were introduced which referred to the "provinces" of the Roman empire ${ }^{58}$. Many slogans were applied in reference to the provinces and the entire Danube area of the Roman state: DACIA ${ }^{59}$, DACIA FELIX ${ }^{60}$, PANNONIAE (S C $)^{61}$, EXERCITVS INLVRICVS S C ${ }^{62}$, GENIVS

\footnotetext{
${ }^{57}$ A.C. Levi, Barbarians on Roman Imperial Coins and Sculpture, New York 1952, p. 27.

${ }^{58}$ J.A. Ostrowski, Les personnifications des provinces dans l'art romain, Varsovie 1990, p. 61-62; A.A. Kluczek, VNDIQVE VICTORES..., p. 71-75; M. Vitale, Das Imperium in Wort und Bild. Römische Darstellungsformen beherrschter Gebiete in Inschriftenmonumenten, Münzprägungen und Literatur, Stuttgart 2017, p. 252-255. The extent of the presence of such themes in Decius's coinage was established by Erika Manders; geographical references $-35.6 \%$ of coins, only military themes were represented more frequently: $37.5 \%$ of coins. Cf. E. MAnders, Coining Images of Power. Patterns in the Representation of Roman Emperors on Imperial Coinage, A.D. 193-284, Leiden-Boston 2012 [= IE, 15], p. 256-257.

${ }^{59}$ H. Mattingly, E.A. Sydenham, C.H.V. Sutherland, The Roman Imperial Coinage, vol. IV.3, Gordian III - Uranius Antoninus, London 1968 [repr.] (cetera: RIC 4.3), Tr. D., nos 2, 12-13 (au, Rome), 35-36 (au, Milan), 101, 112-113 (ses/dp/as, Rome).

${ }^{60}$ RIC 4.3, Tr. D., nos 14 (au, Rome), 37 (au, Milan), 114 (ses/as, Rome). Cf. Corpus Inscriptionum Latinarum, ed. T. Mommsen et al., Berolini 1863- (cetera: CIL), 03, 1176: restitutor Daciarum; CIL 02, 4949, 4957-4958: Dacicus maximus. The emperor's epithet refers to the fighting in Dacia in 250. ${ }^{61}$ RIC 4.3, Tr. D., nos 5 (au, Rome), 20-26 (au/ant, Rome), 41 (au, Milan), 124 (ses, Rome); RIC 4.3, Tr. D. (Her. Etr.), no 158 (ant, Antioch); RIC 4.3, Tr. D. (Host.), no 195 (ant, Antioch).

${ }^{62}$ RIC 4.3, Tr. D., no 102 (ses/as, Rome).
} 
EXERCITVS ILLVRICIANI (S C) ${ }^{63}$, GENIO EXERC ILLYRICIANI ${ }^{64}$, GEN ILLVRICI (S C $)^{65}$. The provinces of Dacia and Pannonia returned to the imperial coins after a long period of absence: Dacia previously featured in the coinage of Antoninus Pius (138-161) ${ }^{66}$; Pannonia previously featured during Hadrian's reign $(117-138)^{67}$. However, references to the entire Illyricum were a novelty. As far as the themes are concerned, the entire group of these "regional" issues of Trajan Decius was limited to the Danube lands. Such a geographical preference may have been a result of the fact that this was the area of origin of the emperor ${ }^{68}$ and that military activities were conducted there. The exposure of these areas to external danger and the necessity to organise a defence there are perhaps indicated by the military standards held by the personified provinces ${ }^{69}$. Also, the employment of the types of VICTORIA AVG (cf. figs 8-9) ${ }^{70}$ and VICTORIA GERMANICA (fig. 10) ${ }^{71}$ is an indication that the problem of the strangers-enemies was perceived in the content represented in coins.

${ }^{63}$ RIC 4.3, Tr. D., nos 3-4 (au, Rome), 16-18 (au/ant/q/d, Rome), 39-40 (ant, Milan), 103-105 (ses, Rome), 117-119 (ses/dp/as, Rome).

${ }^{64}$ P. Gysen, Légende de revers au datif pour un antoninien de Trajan Dèce, BCEN 36.3, 1999, p. 75-76 (ant, Rome).

${ }^{65}$ RIC 4.3, Tr. D., nos 9 (au, Rome), 15 (ant, Rome), 38 (ant, Milan), 116 (ses, Rome).

${ }^{66}$ H. Mattingly, E.A. Sydenham, The Roman Imperial Coinage, vol. III, Antoninus Pius to Commodus, London 1968 [repr.], Ant. P., no 581 (ses, Rome): DACIA COS II S C, Dacia standing, holding crown and standard.

${ }^{67}$ H. Mattingly, E.A. Sydenham, The Roman Imperial Coinage, vol. II, Vespasian to Hadrian, London 1968 [repr.], Hadr. (L. Aelius Caesar), nos 1059-1060 (ses, Rome), 1071-1073 (dp/as, Rome): TR POT COS II PANNONIA S C.

${ }^{68}$ Aurélius Victor, Liber de Caesaribus. Livre des Césars, 29.1, ed. et trans. P. Dufraigne, Paris 1975 [= CUF] (cetera: Aurelius Victor); Eutropius, Breviarium ab Urbe condita. Eutrope, Abrégé d'histoire romaine, 9.4, ed. et trans. J. Hellegouarc'H, Paris 1999 [= CUF.SL]; Pseudo-Aurelius Victor, Epitome de Caesaribus. Abrégé des Césars, 29.1, ed. et trans. M. Festy, Paris 1999 [= CUF. SL]. Decius's career and nomina - cf. X. LORIOT, Un sénateur illyrien élevé à la pourpre: Trajan Dèce, [in:] Les empereurs illyriens, ed. E. Frézouls, H. Jouffroy, Strasbourg 1998, p. 44-55; A.R. Birley, Decius Reconsidered, [in:] Les empereurs illyriens..., p. 57-77.

${ }^{69}$ C. Heitz, Die Guten, die Bösen und die Hässlichen. Nördliche 'Barbaren' in der römischen Bildkunst, Hamburg 2009 [= SAnt, 48], p. 137; E. MANDERs, Coining Images..., p. 258.

${ }^{70}$ RIC 4.3, Tr. D., nos 7 (au, Rome), 29 (au/q/ant), 42 (au/q, Milan), 48 (ant, Antioch), 108 (ses/dp, Rome), 126 (2ses/ses/as, Rome); RIC 4.3, Tr. D. (Herennia Etruscilla), no 70 (ant, Antioch); RIC 4.3, Tr. D. (Her. Etruscus), no 161 (ant, Antioch); RIC 4.3, Tr. D. (Host.), no 201 (ant, Antioch); RIC 4.3, Host., nos 208-209 (ant, Antioch).

${ }^{71}$ RIC 4.3, Tr. D., no 43 (ant, Milan); RIC 4.3, Her. Etr., no 154 (ant, Rome); RIC 4.3, Tr. D. (Host.), no 185 (ant, Rome). 


\section{Final remarks}

The theme of the barbarian in Trajan Decius's coinage was not a popular one. It was engaged in four mints and in a few iconographic models. This is a scant number, considering the number of all provincial mints which operated in the period 249-251 and the plenitude of the types which were developed in them.

Nevertheless, this small group of provincial coins featuring the barbarian theme enables us to make a number of generalisations. In contrast to imperial coinage, the provincial coins featured literal references to the non-Roman world, symbolised by the figure of the enemy or captive. This foreign world was outlined in the iconography, either allusively (in imperial coins) or directly (in provincial coins). Moreover, it existed exclusively as a hostile world, a world which was being vanquished or eventually vanquished by the Romans.

The presence of the barbarian theme in provincial coinage indicates that in individual cases - in these few mints - the concerns resulting from the situation of the empire attacked by the barbarians at that time were expressed. This does not rule out the fact that the idea of the glorification of the ruler(s) as the victor(s) was embedded in the same representations. The echoes of the fighting against the barbarians could - even though it was absent in imperial coinage - revive this idea in provincial mintage.

The merit of the conquering of enemies - symbolised by the barbarian theme - was ascribed to Trajan Decius; the role of the victor was also sporadically played by Herennius Etruscus. This limiting to two of the three male members of the ruling family perhaps reflects their actual participation in military campaigns, in the undertaking of which the emperor was supported by his elder son, who operated in Illyricum since $250^{72}$.

The defeats suffered in 251 at the end of Trajan Decius's rule marked a turning point in the practice of the employment of the barbarian theme in provincial coinage. In the period of his direct successors, Trebonianus Gallus and Volusianus (251-253), one may perceive - in the figure kneeling before Roma in the iconography of the coins from Antioch - an image of a barbarian ${ }^{73}$.

\footnotetext{
${ }^{72}$ Aurelius Victor, 29.1. See: J.F. Salisbury, H. Mattingly, The Reign of Trajan Decius, JRS 14, 1924, p. 14-18; U. Huttner, Von Maximinus Thrax bis Aemilianus..., p. 208-211.

${ }^{73}$ RPC 9, no 1278, obv.: IMP C VIMP GALVSSIANO AVG; radiate, draped and cuirassed bust of Volusian, r.; rv.: ANTIOCHI OCL A, S R; Roma seated on throne, r., holding sceptre and Nike; at feet, captive kneeling, l. The identity of the kneeling figure is not obvious at all. Cf. A. KrzyżANowsKa, Monnaies coloniales d'Antioche de Pisidie, Warszawa 1970, p. 77, 196, VI/18: the position of the suppliant bears a resemblance to the personification of the province which kneels before the emperor. The suppliant may symbolise the inhabitants of Antioch, towards whom Roma is a benefactress. Note: the poorly legible attributes of Roma were interpreted to be a tessera (?) and a cornucopia, the symbols of Liberalitas and Fortuna. However, Roma holds a sceptre and the figurine of the goddess of victory.
} 


\section{Appendix}

Nicomedia, province: Bithynia-Pontus, region: Bithynia

1 Æ, Trajan Decius

obv.: AY(T) KA(I) TPAIAN $\triangle$ EKIOC AYГ [E; radiate and cuirassed bust of emperor, l., holding spear and shield with gorgoneion,

rv.: NIKOMH $\triangle \mathrm{E} \Omega \mathrm{N} \Delta \mathrm{I}[\mathrm{NE} \Omega \mathrm{KOP} \Omega \mathrm{N}$; emperor riding on horse, r., with r. hand spearing

fallen enemy who sits on ground.

Ref.: $R P C$ 9, no 325

2 Æ, Trajan Decius

obv.: AY(T) KA TPAIAN $\triangle \mathrm{EKIO}[\mathrm{A} Г \Gamma[(\mathrm{E})$; radiate and cuirassed bust of emperor, l., holding spear and shield with gorgoneion,

rv.: NIKOMH $\triangle \mathrm{E} \Omega \mathrm{N} \Delta \mathrm{I}[\mathrm{NE} \Omega \mathrm{KOP} \Omega \mathrm{N}$; emperor riding on horse, r., with r. hand spearing small enemy running.

Ref.: $R P C$ 9, no 326

3 Æ, Trajan Decius

obv.: AY KA TPAIAN $\triangle$ EKIO[ AYГ [E; radiate and cuirassed bust of emperor, l., holding spear and shield with gorgoneion,

rv.: NIKOMH $\triangle \mathrm{E} \Omega \mathrm{N} \Delta \mathrm{I}[\mathrm{NE} \Omega \mathrm{KOP} \Omega \mathrm{N}$; emperor on horseback riding, r., with $\mathrm{r}$. hand spearing small enemy running.

Ref.: RPC 9, no 327

Caesarea Maritima, province: Syria Palaestina, region: Samaria

$4 \quad$ Æ, Trajan Decius

obv.: IMP C C MS Q TRA DECIVS AVG; laureate, draped and cuirassed bust of emperor, r., rv.: COL PR F AVG F C CAES MET (PR) (S) (P); emperor riding on galloping horse, r., holding transverse spear; below, at r., small figure of enemy.

Ref.: RPC 9, no 2057

$5 \quad Æ$, Trajan Decius (Herennius Etruscus)

obv.: (C) MES Q EREN ETRVSCO DECIO CAES; radiate, draped, cuirassed bust of caesar, r.,

rv.: COL PR F AV (G) F C CAES MET S P; horseman riding on galloping horse, r., holding transverse spear; below, at $r$., small figure of enemy.

Ref.: RPC 9, no 2084

Magnesia ad Sipylum, province: Asia, region: Lydia

6 Æ, Trajan Decius

obv.: AYT K Г M K TPAIANOC $\triangle E$ KIOC CEB; radiate, draped, cuirassed bust of emperor, r.,

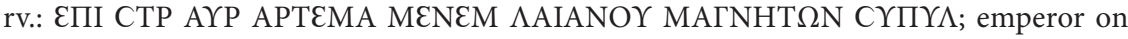
horseback riding, r., with $r$. hand spearing two fallen enemies on the ground.

Ref.: RPC 9, no 572 
$7 \quad$ Æ, Trajan Decius

obv.: AY K Г M K TPAIANOC $\triangle E$ EIOC; radiate, draped, cuirassed bust of emperor, r.,

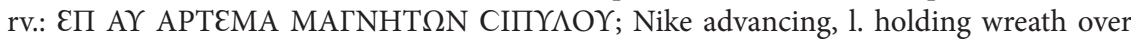
trophy; at her feet, prisoner kneeling.

Ref.: RPC 9, no 573

$8 \quad$ Æ, Trajan Decius

obv.: AY K Г M K TPAIANOC $\triangle E$ KIOC; radiate, draped, cuirassed bust of emperor, r.,

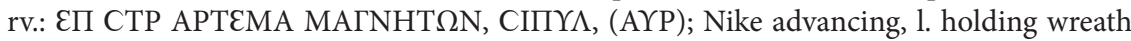
over trophy; at her feet, prisoner kneeling.

Ref.: RPC 9, no 574

\section{Alexandria, province: Egypt, region: Egypt}

9 Tetradrachm, Trajan Decius

obv.: A K Г M K TPAIANOC $\triangle E$ KIOC $\varepsilon$; laureate, draped, cuirassed bust of emperor, r., rv.: L - A; trophy of arms with two shields with, on each side, a bound and seated captive. Ref.: RPC 9, no 2256

10 Tetradrachm, Trajan Decius

obv.: A K Г M K TPAIANOC $\triangle E$ KIOC $\mathcal{E}$; ; laureate, draped, cuirassed bust of emperor, r., rv.: L - A; trophy of arms with two shields with, on each side, a bound and seated captive. Ref.: RPC 9, no 2257

11 Tetradrachm, Trajan Decius obv.: A K $\Gamma$ M K TPAIANOC $\triangle$ EKIOC; laureate and cuirassed bust of emperor, r., rv.: L - B; trophy of arms with two shields with, on each side, a bound and seated captive. Ref.: RPC 9, no 2279

12 obv.: A K Г M K TPAIANOC $\triangle E$ KKIOC $\varepsilon$; laureate and cuirassed bust of emperor, r., rv.: L - B; trophy of arms with two shields with, on each side, a bound and seated captive. Ref.: RPC 9, no 2280

13 Tetradrachm, Trajan Decius (Herennius Etruscus) obv.: K EPE ETP MEC $\triangle$ EKIOC KAIC; bare-headed and cuirassed bust of caesar, r., rv.: L B; horseman riding on galloping horse $r$., with $r$. hand spearing fallen enemy who lies on ground to the r., with $\mathrm{r}$. arm raised.

Ref.: RPC 9, no 2289

14 Tetradrachm, Trajan Decius (Herennius Etruscus)

obv.: K EPE ETP MEC $\triangle$ EKIOC KAICA; bare-headed and cuirassed bust of caesar, r., rv.: $\mathrm{L} \mathrm{B}$; horseman riding on galloping horse $\mathrm{r}$., with $\mathrm{r}$. hand spearing fallen enemy who lies on ground to the r., with $\mathrm{r}$. arm raised.

Ref.: RPC 9, no 2290 


\section{Bibliography}

\section{Primary Sources}

Aurélius Victor, Liber de Caesaribus. Livre des Césars, ed. et trans. P. Dufraigne, Paris 1975 [= Collection des Universités de France].

Corpus Inscriptionum Latinarum, ed. T. Mommsen et al., Berolini 1863-.

Dattari G., Numi Augg. Alexandrini, Cairo 1901.

Eutropius, Breviarium ab Urbe condita. Eutrope, Abrégé d'histoire romaine, ed. et trans. J. HelleGOUARC'H, Paris 1999 [= Collection des Universités de France. Série latine].

Head B.V., A Catalogue of the Greek Coins in the British Museum. Catalogue of the Greek Coins of Lydia, Bologna 1964 [repr.].

Pseudo-Aurelius Victor, Epitome de Caesaribus. Abrégé des Césars, ed. et trans. M. Festy, Paris 1999 [= Collection des Universités de France. Série latine].

Sylloge Nummorum Graecorum Deutschland. Sammlung von Aulock. Lydien, vol. II, ed. G. KLEINER et al., Berlin 1963.

Sylloge Nummorum Graecorum. The Royal Collection of Coins and Medals Danish National Museum. Lydia, Copenhagen 1947.

\section{Roman Provincial Coinage}

Amandry M., Burnett A., Mairat J., Metcalf W., Bricault L., Blet-Lemarquand M., Roman Provincial Coinage, vol. III, Nerva, Trajan and Hadrian (AD 96-138), London-Paris 2015.

Burnett A., Amandry M., Ripollès P.P., Roman Provincial Coinage, vol. I, From the Death of Caesar to the Death of Vitellius (44 BC-AD 69), London-Paris 1992.

Calomino D., Burnett A., Matthies S., Roman Provincial Coinage, vol. VI, From Elagabalus to Maximinus (AD 218-238) (online, with temporary numbers).

Heuchert V., Roman Provincial Coinage, vol. IV.2, The Antonines (AD 138-192): Asia (online, with temporary numbers).

Hostein A., Mairat J., Roman Provincial Coinage, vol. IX, From Trajan Decius to Uranius Antoninus (AD 249-254), London-Paris 2016.

Howgego C., Roman Provincial Coinage, vol. IV.4, The Antonines (AD 138-192): Egypt (online, with temporary numbers).

\section{The Roman Imperial Coinage}

Mattingly H., Sydenham E.A., The Roman Imperial Coinage, vol. II, Vespasian to Hadrian, London 1968 [repr.].

Mattingly H., Sydenham E.A., The Roman Imperial Coinage, vol. III, Antoninus Pius to Commodus, London 1968 [repr.].

Mattingly H., Sydenham E.A., Sutherland C.H.V., The Roman Imperial Coinage, vol. IV.3, Gordian III - Uranius Antoninus, London 1968 [repr.].

\section{Secondary Literature}

Birley A.R., Decius Reconsidered, [in:] Les empereurs illyriens, ed. E. Frézouls, H. Jouffroy, Strasbourg 1998, p. 57-80. 
Bursche A., The Battle of Abritus, the Imperial Treasury and Aurei in Barbaricum, "The Numismatic Chronicle" 173, 2013, p. 151-170.

Christol M., L'empire romain du III siècle. Histoire politique (de 192, mort de Commode à 323, concile de Nicée), Paris 1997.

FERris I.M., Enemies of Rome. Barbarians through Roman Eyes, Stround 2000.

Forrer L., The Weber Collection of Greek Coins, vol. III.1, London 1926.

Grozdanova L., The Roman Emprerors against the Goths of Cniva. Political Mythology, Historical Documents and Retrievable Reality, Sofia 2019.

Gysen P., Légende de revers au datif pour un antoninien de Trajan Dèce, "Bulletin du Cercle d'Etudes Numismatiques" 36.3, 1999, p. 75-77.

Hannestad L., War and Greek Art, [in:] Essays on Warfare in Antiquity, ed. T. Bekker-Nielsen, L. Hannestad, København 2001, p. 146-154.

Heitz C., Alles bare Münze? Fremdendarstellungen auf römischem Geld, "Bonner Jahrbücher” 206, 2006, p. 159-230.

Heitz C., Die Guten, die Bösen und die Hässlichen. Nördliche 'Barbaren' in der römischen Bildkunst, Hamburg 2009 [= Schriftenreihe Antiquitates, 48].

Huttner U., Von Maximinus Thrax bis Aemilianus, [in:] Die Zeit der Soldaten-Kaiser. Krise und Transformation der Römischen Reiches im 3. Jahrhundert n.Chr. (235-284), ed. K.-P. JoHnE, U. Hartmann, T. Gerhardt, Berlin 2008, p. 161-221.

Kellner W., Die Münzstätte Alexandria in Ägypten von Kleopatra bis Arcadius, Wien 2009.

KLuczeK A.A., Empereur invaincu et barbares. Les représentations des barbares dans le monnayage romain de l'époque impériale (235-284 apr. J.-C.), [in:] Rzym antyczny. Polityka i pieniądz. The Ancient Rome. Politics and Money IV, ed. W. Kaczanowicz, Katowice 2008, p. 104-134.

KLUCZeK A.A., VNDIQVE VICTORES. Wizja rzymskiego władztwa nad światem w mennictwie złotego wieku Antoninów i doby kryzysu III wieku - studium porównawcze, Katowice 2009.

KLUCZeK A.A., Wizerunek „obcego-wroga” w ikonografi monetarnej. Przykład mennictwa cesarza rzymskiego Aureliana (270-275), [in:] Grecy, Rzymianie i ich sasiedzi, ed. K. NawOtKA, M. PAwLak, A. Paeuchowski, A. Wojciechowska, Wrocław 2007, p. 305-326.

Kotula T., Barbarzyńcy i dworzanie. Rzym a barbarzyńcy w dworskiej literaturze późnorzymskiej, Kraków 2004.

Kotula T., Cesarz Klaudiusz II i Bellum Gothicum lat 269-270, Wrocław 1994 [= Acta Universitatis Wratislaviensis. Antiquitas].

KotUla T., Kryzys III wieku w zachodnich prowincjach cesarstwa rzymskiego, Wrocław 1992 [= Acta Universitatis Wratislaviensis. Antiquitas].

Kraft K., Das System der kaiserzeitlichen Münzprägung in Kleinasien. Materialien und Entwürfe, Berlin 1972 [= Istanbuler Forschungen, 29].

Krzyżanowska A., Monnaies coloniales d'Antioche de Pisidie, Warszawa 1970.

Levi A.C., Barbarians on Roman Imperial Coins and Sculpture, New York 1952.

Levine L., Some Observations on the Coins of Caesarea Maritima, "Israel Exploration Journal" 22.2/3, 1972, p. 131-140.

LoRIOT X., Un sénateur illyrien élevé à la pourpre: Trajan Dèce, [in:] Les empereurs illyriens, ed. E. Frézouls, H. Jouffroy, Strasbourg 1998, p. 43-55. 
Manders E., Coining Images of Power. Patterns in the Representation of Roman Emperors on Imperial Coinage, A.D. 193-284, Leiden-Boston 2012 [= Impact of Empire, 15], https://doi.org/ $10.1163 / 9789004224001$

Mattern S.P., Rome and the Enemy. Imperial Strategy in the Principate, Berkeley-Los AngelesLondon 1999, https://doi.org/10.1525/9780520929708

Ostrowsкi J.A., „Cum restrictis ad terga manibus”. Wizerunki jeńców wojennych jako element rzymskiej propagandy politycznej, [in:] Niewolnictwo i niewolnicy w Europie od starożytności po czasy nowożytne, ed. D. Quirini-PopŁawsKa, Kraków 1998, p. 41-47.

Ostrowski J.A., Les personnifications des provinces dans l'art romain, Varsovie 1990.

Peachin M., Roman Imperial Titulature and Chronology, A.D. 235-284, Amsterdam 1990.

PiCARD G.C., Les trophées romains. Contribution à l'histoire de la Religion et de l'Art triomphal de Rome, Paris 1957.

Salisbury J.F., Mattingly H., The Reign of Trajan Decius, "Journal of Roman Studies" 14, 1924, p. 1-23, https://doi.org/10.2307/296323

Vitale M., Das Imperium in Wort und Bild. Römische Darstellungsformen beherrschter Gebiete in Inschriftenmonumenten, Münzprägungen und Literatur, Stuttgart 2017.

\begin{abstract}
During Trajan Decius's reign (249-251) in a number of provincial mints - Alexandria, Caesarea Maritima, Magnesia ad Sipylum and Nicomedia - coins were issued featuring the theme of the barbarian (an enemy or a captive) in reverse iconography. In this article, I discuss these coins, considering them in the context of the iconographic tradition and the activity of the particular mints during Decius's reign, and also in relation to the ideology of victory and the dynastic ideology. They are interesting especially because the theme of the barbarian was not utilised in the parallel imperial coinage. Nevertheless, its presence in provincial coinage is also of a marginal nature. Moreover, the end of Decius's reign also coincided with a time-related hiatus in the use of the theme in provincial coinage.
\end{abstract}

Keywords: Trajan Decius, Roman provincial coins, barbarians

Agata A. Kluczek

University of Silesia in Katowice Faculty of Humanities Institute of History

ul. Bankowa 11, p. 134

40-007 Katowice, Polska/Poland agata.kluczek@us.edu.pl 


\section{ILLUSTRATIONS}
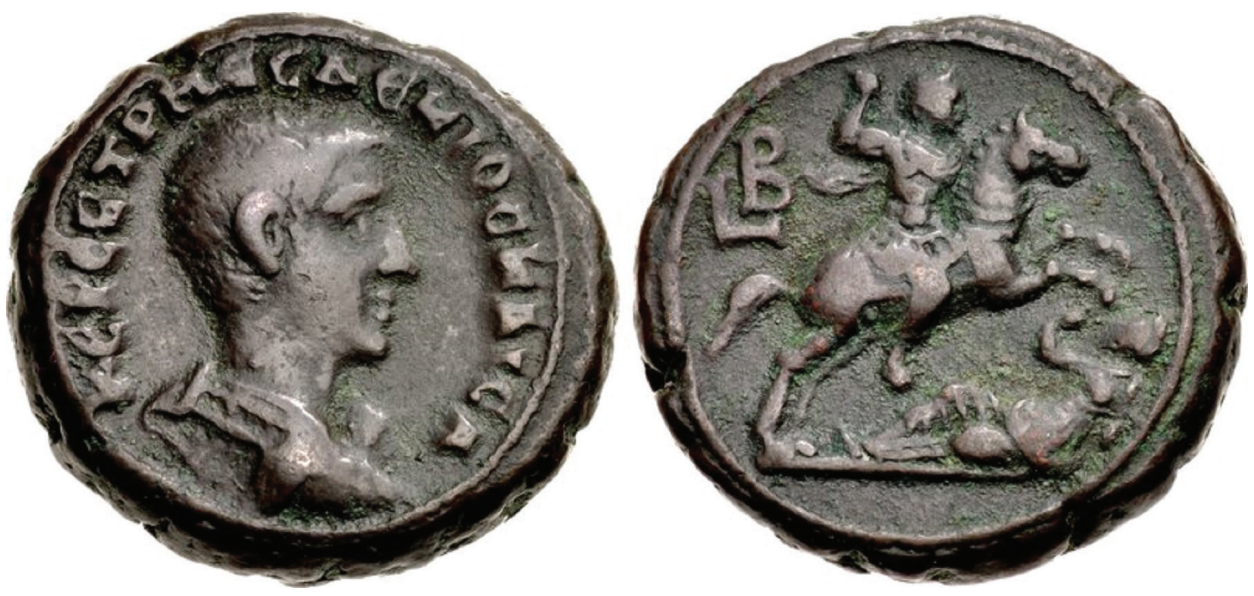

Fig. 1. Tetradrachm, Alexandria (Egypt), Trajan Decius (Herennius Etruscus), 250/251 AD; obv.: K EPE ETP MEC $\triangle$ EKIOC KAICA, bareheaded, draped, and cuirassed bust, r.; rv.: caesar on horseback galloping, r., thrusting spear at fallen enemy below horse / L B; cf. RPC 9, no 2290 [www.cngcoins.com/Coin.aspx?CoinID=381421]
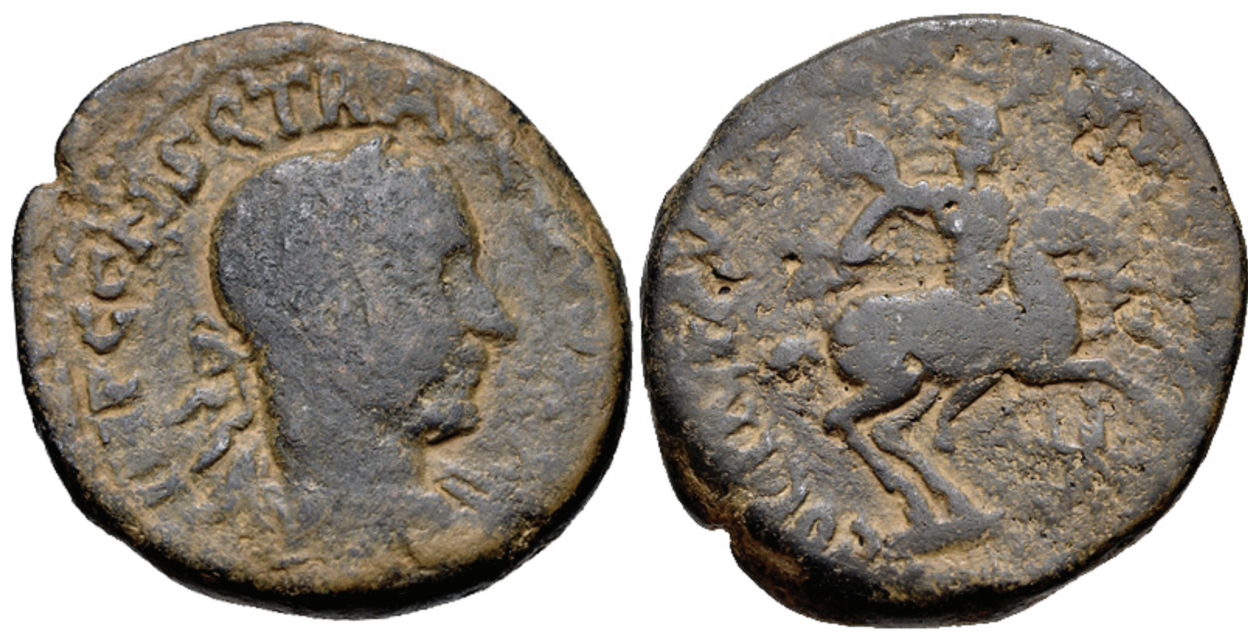

Fig. 2. Æ, Caesarea Maritima (Samaria), Trajan Decius, (249-251 AD); obv.: IMP C C MS Q TRA DECIVS AVG, laureate, draped and cuirassed bust, r.; obv.: COL PR F AV [G F C CAES MET PR S P], emperor riding on galloping horse, r., holding transverse spear; below, at r., small enemy; cf. RPC 9, no 2057 [www.cngcoins.com/Coin. aspx?CoinID=290511] 

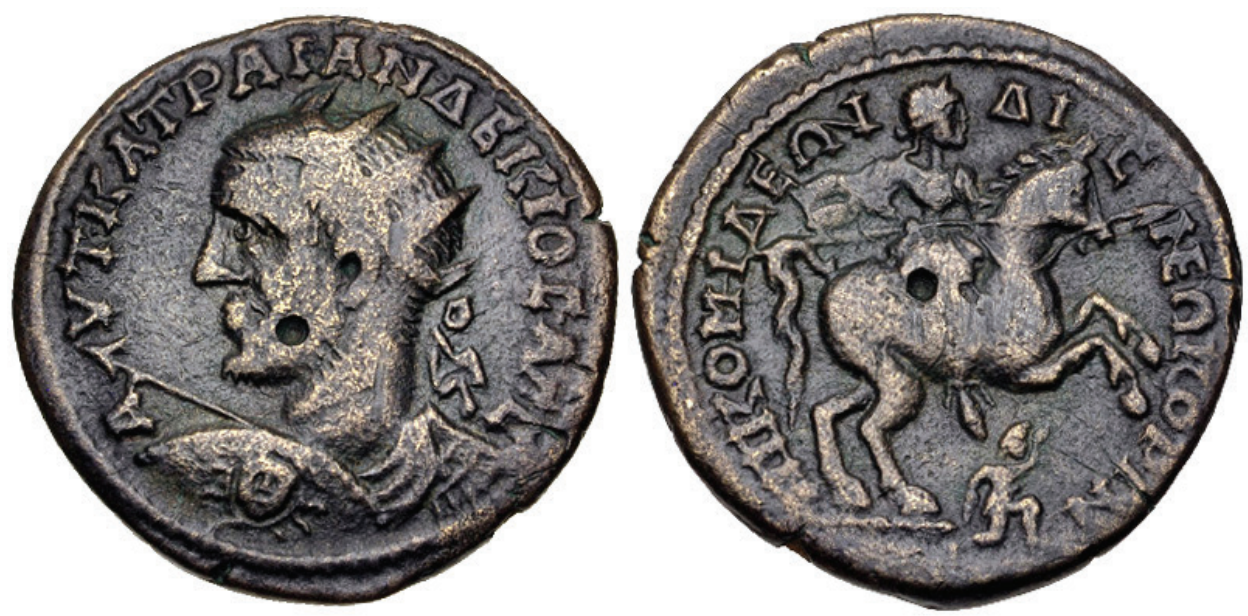

Fig. 3. Æ, Nicomedia (Bithynia), Trajan Decius, (249-251 AD); obv.: AYT KA TPAIAN $\triangle \mathrm{EKIO}[\mathrm{A} \Gamma[\mathrm{E})$, radiate and cuirasse bust., l., holding spear and shield, which is ornamented with a gorgoneion; rv.: NIKOMH $\triangle \mathrm{E} \Omega \mathrm{N} \triangle \mathrm{I}[\mathrm{NE} \Omega \mathrm{KOP} \Omega \mathrm{N}$, emperor on horseback, r., holding spear; below horse, small enemy running, r.; cf. $R P C$ 9, no 326 [www.cngcoins.com/Coin.aspx?CoinID=391374]
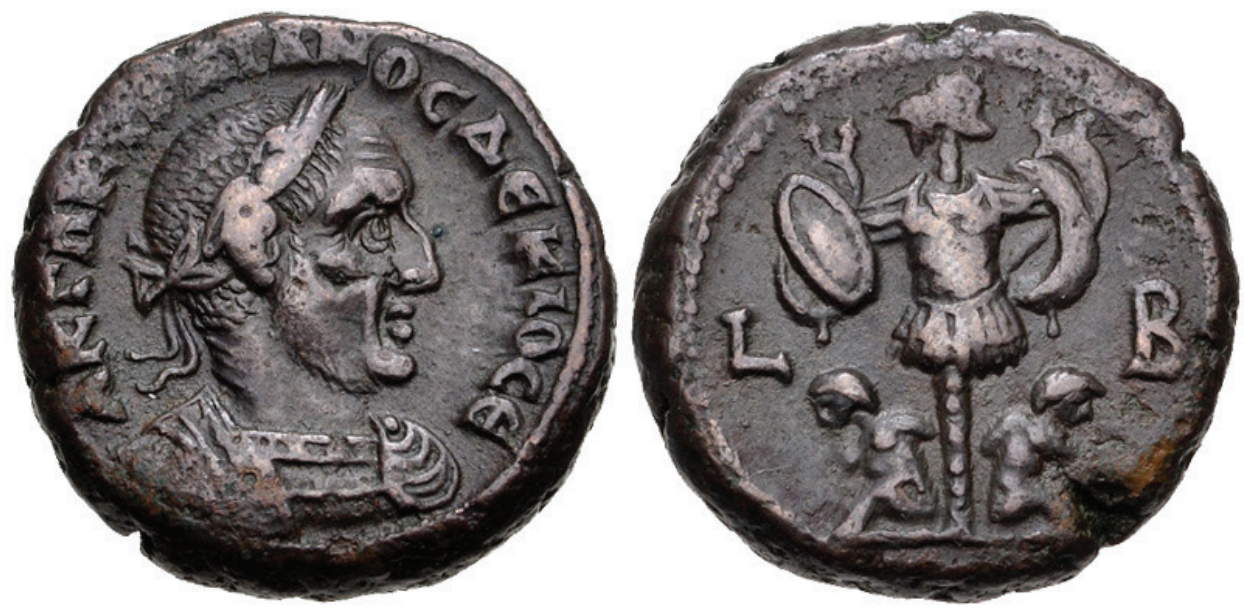

Fig. 4. Tetradrachm, Alexandria (Egypt), Trajan Decius, 250/251 AD; obv.: A K Г M K TPAIANOC $\triangle$ EKIOC $\mathcal{E}$, laureate and cuirassed bust, r.; rv.: trophy with two captives / L B; cf. $R P C$ 9, no 2280 [www.cngcoins.com/Coin.aspx?CoinID=306427] 

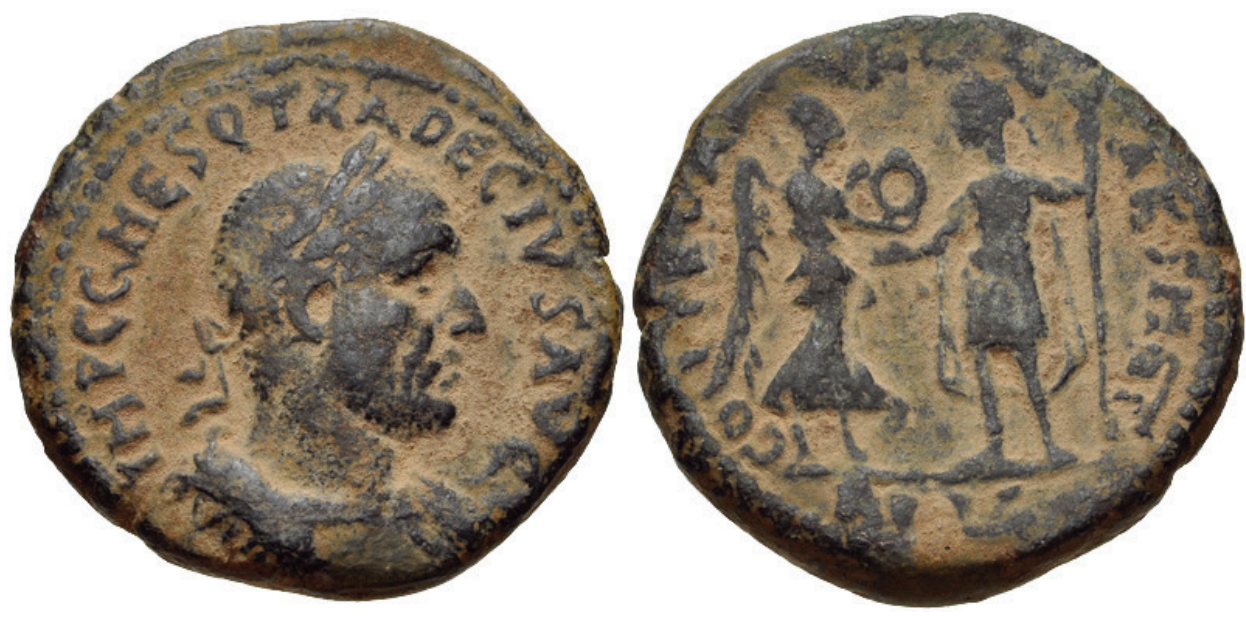

Fig. 5. Æ, Caesarea Maritima (Samaria), Trajan Decius, (249-251 AD); obv.: IMP C C MES Q TRA(I) DECIVS AVG, laureate and cuirassed bust, r.; rv.: COL PR F AVG F C CAES MET / R PSP, emperor standing, l., holding spear, receiving wreath from Victory / Nike standing r.; cf. RPC 9, no 2058 [www.cngcoins.com/Coin.aspx?CoinID=151101]
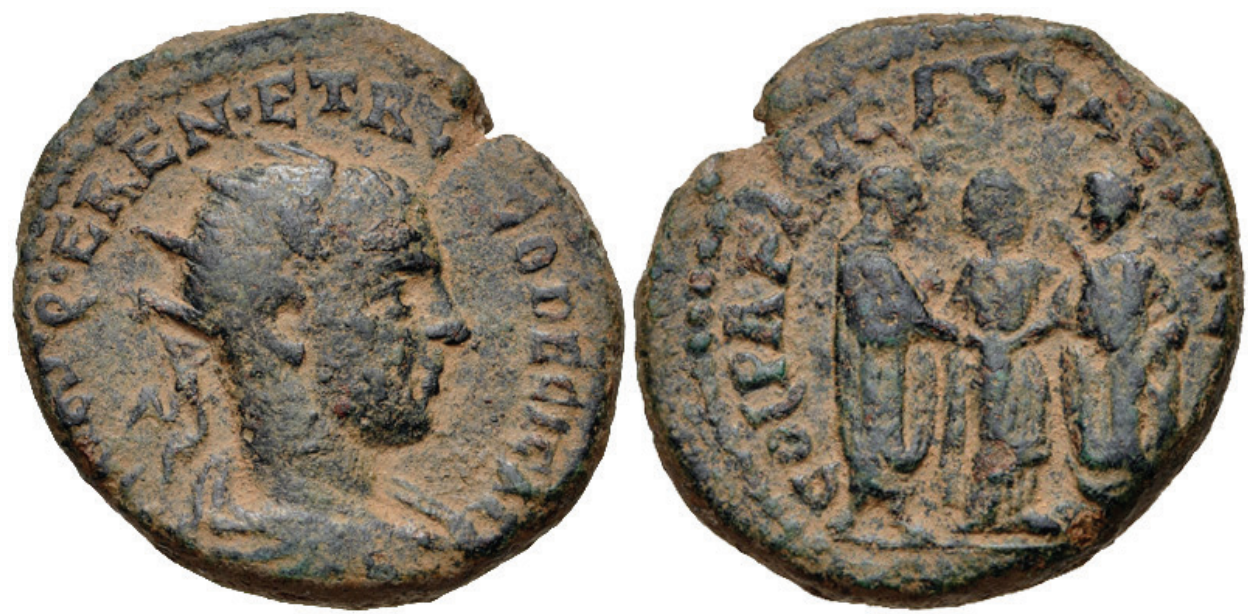

Fig. 6. Æ, Caesarea Maritima (Samaria), Trajan Decius (Herennius Etruscus), (249-251 AD); obv.: MES Q ERE ETRVSCO DECIO CAES, radiate and draped bust, r.; rv.: COL PR F AVG F C CAES MET S P, Herennia Etruscilla standing facing between Trajan Decius, r., and Herennius Etruscus, l., clasping hands; cf. RPC 9, no 2082 [www.cngcoins.com/ Coin.aspx?CoinID=278097] 

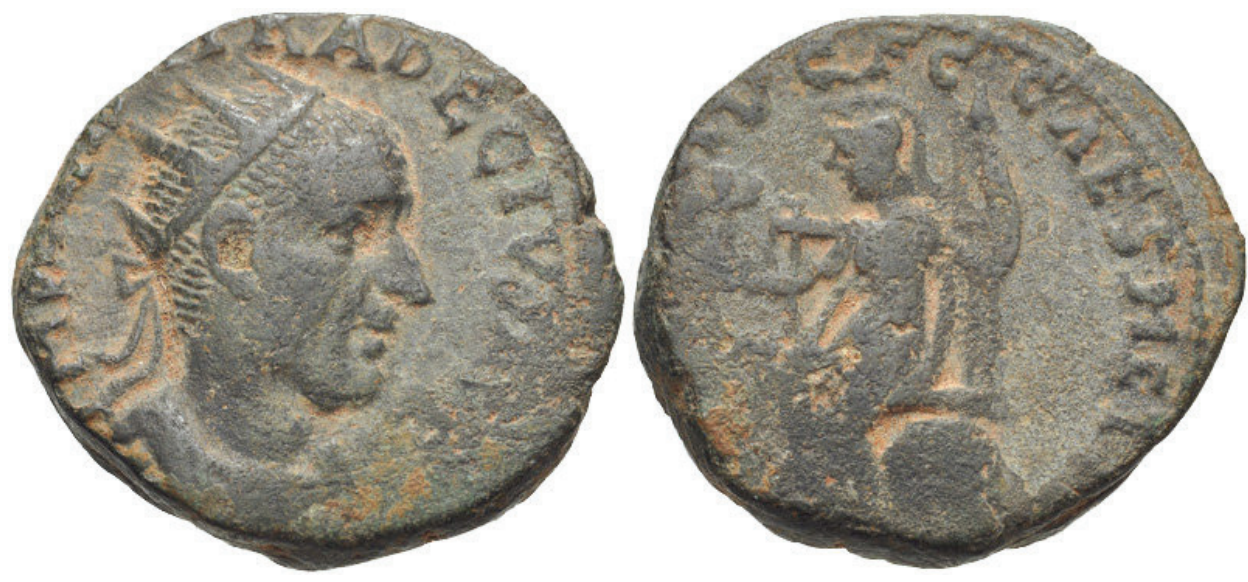

Fig. 7. Æ, Caesarea Maritima (Samaria), Trajan Decius, (249-251 AD); obv.: IMP C C MES Q TRAIANVS DECIVS AVG, radiate and draped bust, r.; rv.: [COL PR F] AVG F C CAES METRO, Roma seated, 1., on shield, holding Nike and spear; cf. RPC 9, no 2065 [www.cngcoins.com/Coin.aspx?CoinID=139067]
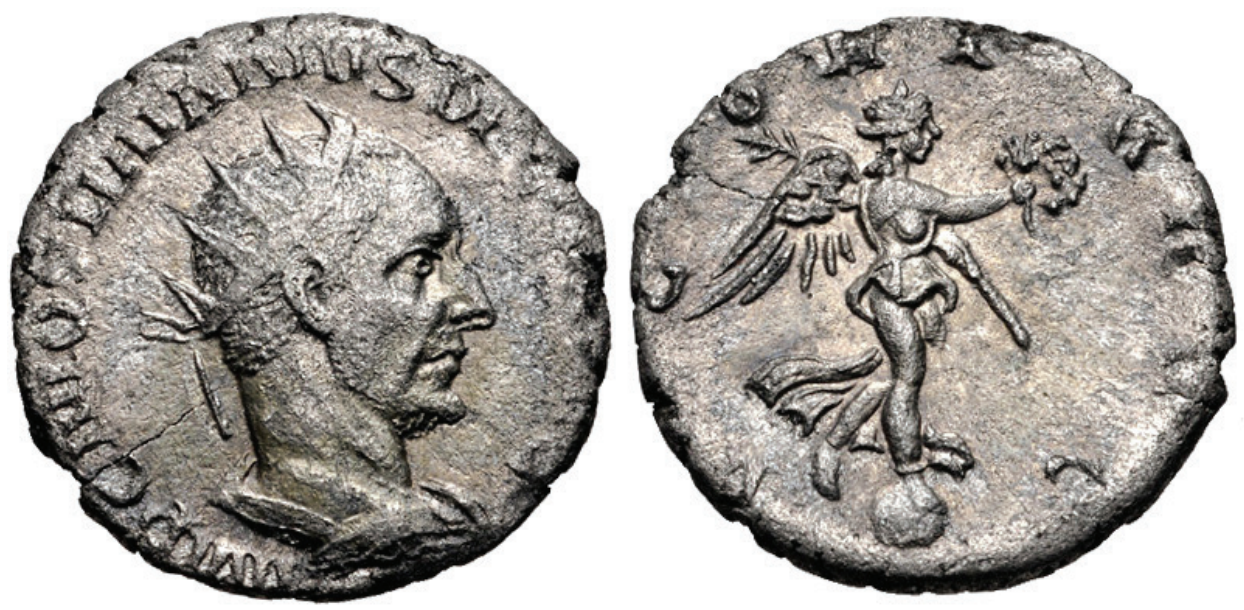

Fig. 8. Ant, Antioch?, Trajan Decius, 251 AD; obv.: IMP C M Q TRAIANVS DE[CIVS AVG], radiate and cuirassed bust, r.; rv.: V[I]C[T]ORIA AVC, Victory standing on globe, r., holding wreath and palm [www.cngcoins.com/Coin.aspx?CoinID=250028] 

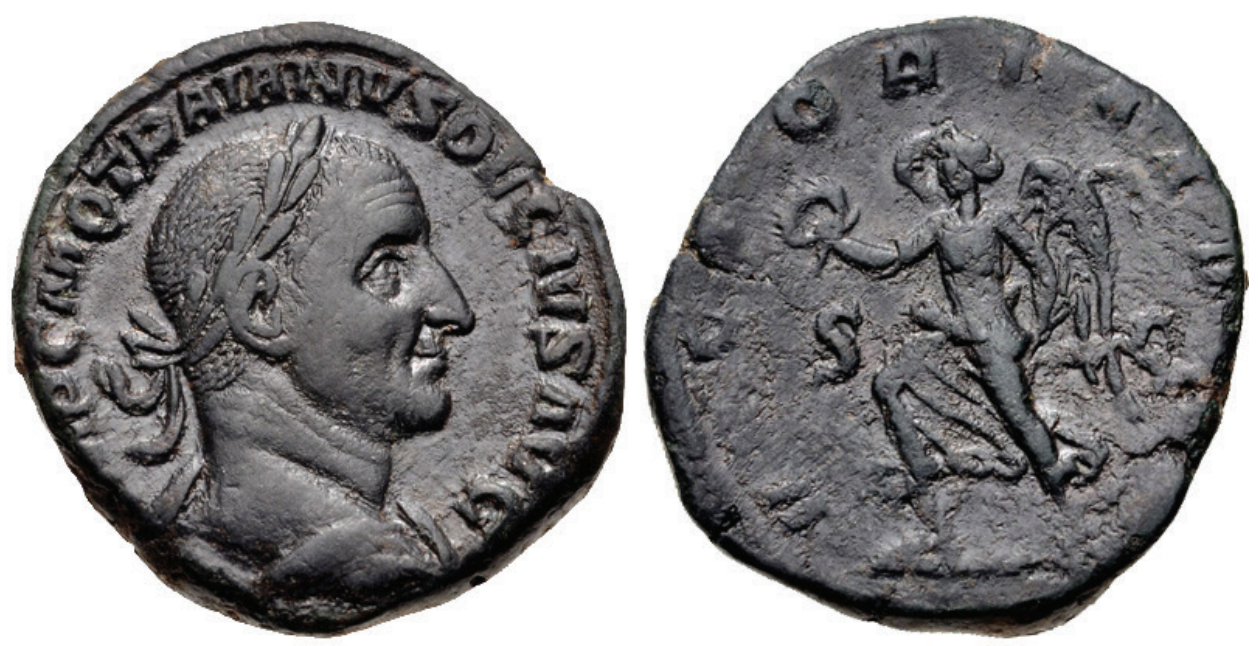

Fig. 9. Ses, Rome, Trajan Decius, 249-250 AD; obv.: IMP C M Q TRAIANVS DECIVS AVG, laureate and cuirassed bust, r.; rv.: VICTORIA AVG S C, Victory advancing, 1., holding wreath and palm; cf. RIC 4.3, Tr. D., no 126d [www.cngcoins.com/Coin.aspx? CoinID=253743]
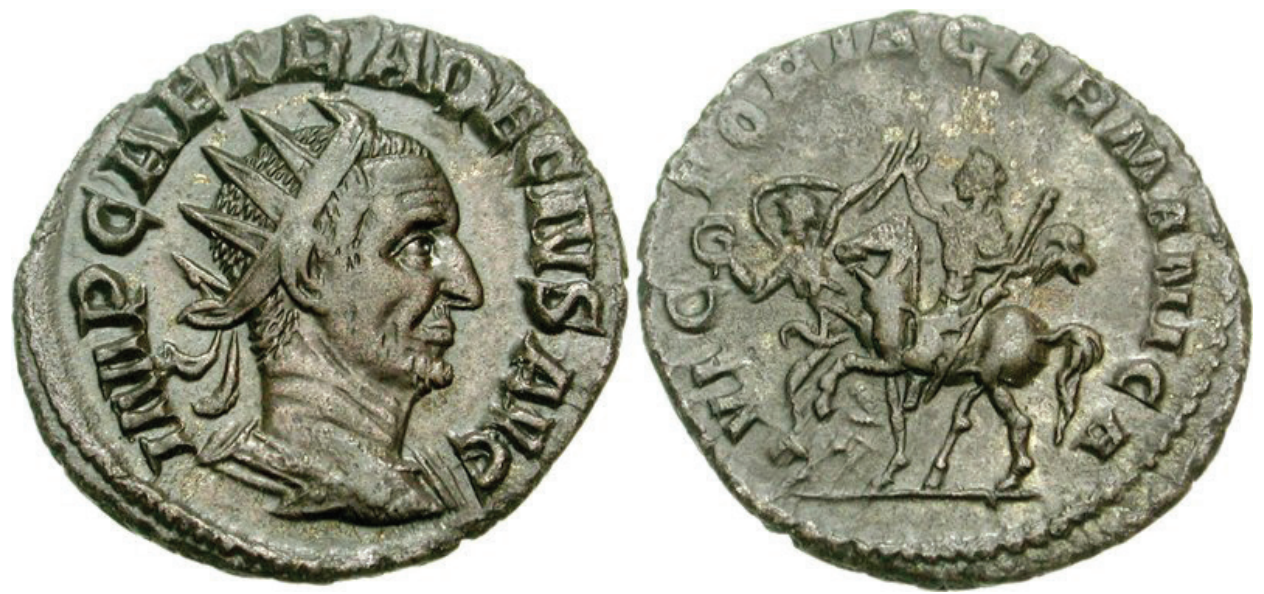

Fig. 10. Ant, Rome, Trajan Decius, 251 AD; obv.: IMP CAE TRA DECIVS AVG, radiate, draped, and cuirassed bust, r.; rv.: VICTORIA GERMANICA, emperor on horseback riding 1., raising r. hand and holding sceptre in 1., Victory advancing 1., holding wreath and palm; cf. RIC 4.3, Tr. D., no 43 corr. [www.cngcoins.com/Coin.aspx?CoinID=153115] 